\title{
Flavobacterium beibuense sp. nov., isolated from marine sediment
}

\author{
Yuanyuan Fu, ${ }^{1} \dagger$ Xixiang Tang, ${ }^{1} \dagger$ Qiliang Lai, ${ }^{1}$ Chunhua Zhang, ${ }^{2}$ \\ Huanzi Zhong, ${ }^{1}$ Weiwei Li, ${ }^{1}$ Yuhui Liu, ${ }^{1}$ Liang Chen, ${ }^{1,3}$ Fengqin Sun ${ }^{1}$ \\ and Zongze Shao ${ }^{1}$
}

Correspondence

Zongze Shao shaozz@163.com

\author{
${ }^{1}$ Key Laboratory of Marine Biogenetic Resources, Third Institute of Oceanography, State Oceanic \\ Administration, Xiamen 361005, PR China \\ ${ }^{2}$ Marine Environmental Monitor Center of Beihai, State Oceanic Administration, Beihai 536000,
PR China \\ ${ }^{3}$ State Key Laboratory of Agricultural Microbiology, National Engineering Research Centre of \\ Microbial Pesticides, College of Life Science and Technology, Huazhong Agricultural University, \\ Wuhan 430070, PR China
}

In an attempt to investigate crude-oil-degrading bacteria in the marine sediment of the Beibu Gulf, PR China, many bacterial strains were isolated and characterized taxonomically. One of these isolates, designated strain $F 44-8^{T}$, is described in this study. $16 \mathrm{~S}$ rRNA gene sequence analysis indicated that strain $\mathrm{F} 44-8^{\mathrm{T}}$ formed a distinct lineage in the genus Flavobacterium. The genus Flavobacterium (Bergey et al., 1923; Bernardet et al., 1996; Bernardet \& Bowman, 2006) is the type genus of the family Flavobacteriaceae, which currently contains 88 genera with validly published names (http://www.bacterio.cict.fr/). Flavobacterium strains have been isolated from a variety of environments (Bernardet \& Bowman, 2006) and they have previously been reported from soil samples contaminated with engine

†These authors contributed equally to this work.

Abbreviation: NJ, neighbour-joining.

The GenBank/EMBL/DDBJ accession number for the $16 \mathrm{~S}$ rRNA gene sequence of strain $F 44-8^{\top}$ is GQ245972.

A supplementary figure is available with the online version of this paper. oil (Mandri \& Lin, 2007). The aim of the present study was to determine the exact taxonomic position of strain $\mathrm{F} 44-8^{\mathrm{T}}$ by using a polyphasic characterization including the determination of phenotypic properties and a detailed phylogenetic analysis based on 16S rRNA gene sequences.

Marine sediment was sampled at site no. $44\left(21^{\circ} 26^{\prime} 12.50^{\prime \prime}\right.$ $\left.\mathrm{N} 109^{\circ} 40^{\prime} 21.90^{\prime \prime} \mathrm{E}\right)$ in the Beibu Gulf in October 2008. The sample was enriched with crude oil $(1 \%, w / v)$ and the strains were isolated on $216 \mathrm{~L}$ marine agar (sodium acetate, $1.0 \mathrm{~g}$; tryptone, $10.0 \mathrm{~g}$; yeast extract, $2.0 \mathrm{~g}$; sodium citrate, $0.5 \mathrm{~g} ; \mathrm{NH}_{4} \mathrm{NO}_{3}, 0.2 \mathrm{~g}$; seawater, $1 \mathrm{l} ; \mathrm{pH} 7.5$ ) according to Lai et al. (2009). For morphological and biochemical characterization, strain $\mathrm{F} 44-8^{\mathrm{T}}$ was cultivated on marine agar 2216 (MA; BD Difco).

Genomic DNA was prepared according to the method of Ausubel et al. (1995); the 16S rRNA gene was amplified by PCR using previously described primers (Liu \& Shao, 2005). Sequences of related taxa were obtained from GenBank. Phylogenetic analysis was performed using MEGA4 (Tamura et al., 2007) and DNAMAN (version 5.1; 
Lynnon Biosoft) according to Lai et al. (2009). Evolutionary distances were calculated using the algorithm of Kimura's two-parameter model (Kimura, 1980). Distances (distance options according to Kimura's two-parameter model) and clustering with the neighbour-joining (NJ; Saitou \& Nei, 1987) and minimum-evolution (Rzhetsky \& Nei, 1992, 1993) methods were determined by using bootstrap values based on 1000 replications.

A nearly full-length $16 \mathrm{~S}$ rRNA gene sequence (1480 bp) of strain $\mathrm{F} 44-8^{\mathrm{T}}$ was determined and about 1360 positions were used for sequence alignment and phylogenetic analysis. The 16S rRNA gene sequence of strain F44- $8^{\mathrm{T}}$ showed highest similarities to those of Flavobacterium frigoris $\mathrm{LMG} 21922^{\mathrm{T}}(93.3 \%)$, Flavobacterium terrae R2A1$13^{\mathrm{T}}(93.3 \%)$ and Flavobacterium gelidilacus $\mathrm{LMG} 21477^{\mathrm{T}}$ $(93.1 \%)$. Lower similarities were shown to other members of the genus Flavobacterium $(<93.0 \%)$. A tree constructed with the NJ method is shown in Fig. 1. Topology of the minimum evolution tree was essentially the same as that of the NJ tree (not shown). Phylogenetic analyses with all members of the genus Flavobacterium and representative members of the family Flavobacteriaceae revealed that strain $F 44-8^{\mathrm{T}}$ formed a distinct lineage in the genus Flavobacterium. The $16 \mathrm{~S}$ rRNA gene sequence divergences between strain $\mathrm{F} 44-8^{\mathrm{T}}$ and type strains of recognized species were all $\geqslant 6.7 \%$ and, thus, the data support the view that strain $\mathrm{F} 44-8^{\mathrm{T}}$ represents a novel species (Stackebrandt \& Goebel, 1994).

The Gram reaction, catalase, oxidase and lipase (Tween 80) activities, hydrolysis of aesculin, starch, CM-cellulose, agar and DNA, optimal growth temperature (in 216L broth incubated at $4,10,16,20,25,28,30,37,41$ and $42{ }^{\circ} \mathrm{C}$ ) and $\mathrm{pH}$ (in 216L broth adjusted with $\mathrm{HCl}$ and $\mathrm{NaOH}$ to $\mathrm{pH} 4-$ 12 at $1 \mathrm{pH}$ unit intervals), and tolerance of $\mathrm{NaCl}$ (in 216L broth adjusted to $0,0.5,1,3,5,7,10,12$ and $15 \% \mathrm{NaCl}$ ) were studied as described previously (Dong \& Cai, 2001). The presence of flexirubin-type pigments and gliding motility were tested as recommended by Bernardet et al. (2002). Other biochemical tests were carried out at $28{ }^{\circ} \mathrm{C}$ using API 20NE, API 20E, API ZYM and API 50CH strips (bioMérieux) according to the manufacturer's instructions, except that the $\mathrm{NaCl}$ concentration was adjusted to $3.0 \%$ in all tests. Antibiotic susceptibility tests were performed on MA (at $28{ }^{\circ} \mathrm{C}$ for $48 \mathrm{~h}$ ) by using the disc diffusion method as described by Shieh et al. (2003). Oxoid discs were used in this study. General cell morphology was studied under an inverted microscope (Olympus IX70) using a day-old culture on MA. For transmission electron microscopy, exponential phase cells were harvested, suspended in double-distilled water, absorbed on a Formvarcarbon-coated grid and stained with phosphotungstic acid (Supplementary Fig. S1, available in IJSEM Online). F. gelidilacus LMG $21477^{\mathrm{T}}$ was grown under the same conditions and included as a reference in the API 20NE and API ZYM tests, as well as in a number of other phenotypic tests. The phenotypic features of strain $\mathrm{F} 44-8^{\mathrm{T}}$ are given in the species description and in Table 1.

Analysis of the respiratory quinones of strain $F 44-8^{\mathrm{T}}$ was carried out by the Identification Service of the DSMZ (Braunschweig, Germany). The major quinone was MK-6 $(99.5 \%)$, which is in accordance with all members of the family Flavobacteriaceae (Bernardet \& Nakagawa, 2006). Minor amounts of MK-5 (0.5\%) were also present. Fatty acids of whole cells grown on MA at $28{ }^{\circ} \mathrm{C}$ for $48 \mathrm{~h}$ were extracted, saponified and esterified; this was followed by GC analysis of the fatty acid methyl esters according to the instructions of the MIDI system (Sasser, 1990). F. gelidilacus LMG $21477^{\mathrm{T}}$ was tested under the same conditions. As shown in Table 2, the major fatty acids of strain $\mathrm{F} 44-8^{\mathrm{T}}$ were iso- $\mathrm{C}_{15: 0}(23.7 \%)$, summed feature 3 (iso- $\mathrm{C}_{15: 0} 2-\mathrm{OH}$ and/or $\mathrm{C}_{16: 1} \omega 7 c ; 16.7 \%$ ), iso- $\mathrm{C}_{15: 1} \mathrm{G}$ $(11.0 \%)$ and iso- $\mathrm{C}_{17: 0} 3-\mathrm{OH}(10.7 \%)$. The overall fatty acid composition of strain $\mathrm{F} 44-8^{\mathrm{T}}$ was similar to that of $F$. gelidilacus LMG $21477^{\mathrm{T}}$ grown under the same conditions.

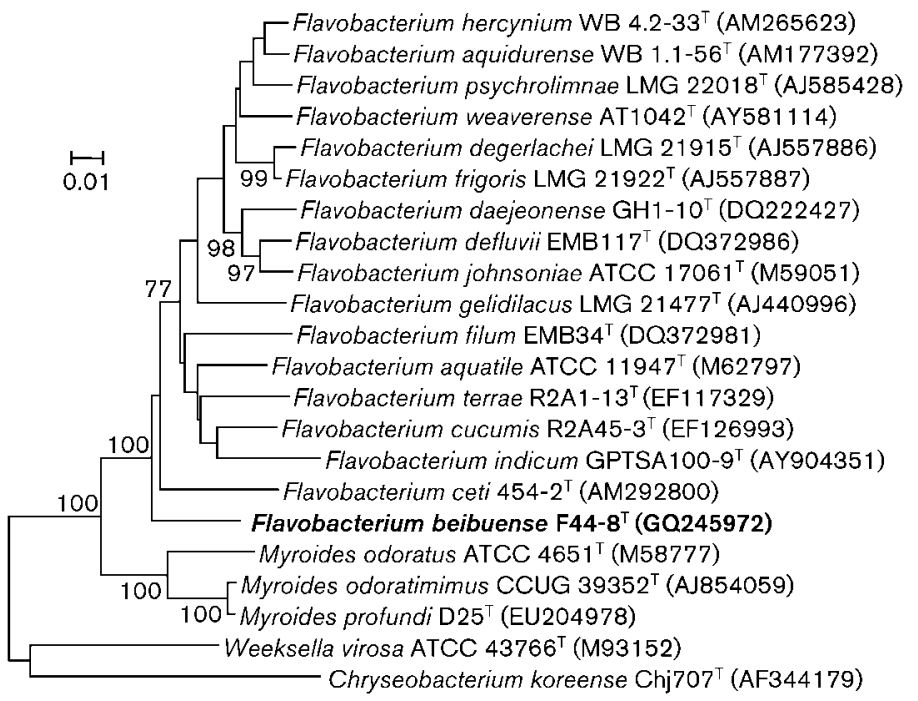

Fig. 1. Neighbour-joining tree showing the estimated phylogenetic positions of strain F44$8^{\top}$ and representatives of related taxa within the family Flavobacteriaceae, based on 16S rRNA gene sequences. Bootstrap values (expressed as percentages of 1000 replications) are shown at branch points. The sequences of Weeksella virosa ATCC $43766^{\top}$ and Chryseobacterium koreense Chj707 ${ }^{\top}$ were used as an outgroup. Bar, 0.01 substitution rate $\left(K_{\text {nuc }}\right)$ units. 
Table 1. Differential characteristics of strain $F 44-8^{\top}$ and related Flavobacterium type strains

Strains: 1, F44- $-8^{\mathrm{T}}$ (data from this study); 2, F. gelidilacus LMG $21477^{\mathrm{T}}$ (unless indicated, data from this study); 3, F. frigoris LMG $21922^{\mathrm{T}}$ (Van Trappen et al., 2004); 4, F. terrae R2A1-13 ${ }^{\mathrm{T}}$ (Weon et al., 2007); 5, F. ceti $454-2^{\mathrm{T}}$ (Vela et al., 2007). +, Positive; -, negative; ND, no data available. Some of the published data listed in this table were obtained using growth conditions and methods different from those used in this study.

\begin{tabular}{|lccccc|}
\hline Characteristic & $\mathbf{1}$ & $\mathbf{2}$ & $\mathbf{3}$ & $\mathbf{4}$ & $\mathbf{5}$ \\
\hline Catalase activity & - & + & + & - & + \\
Growth at $37{ }^{\circ} \mathrm{C}$ & + & - & - & + & + \\
Tolerance of $3 \% \mathrm{NaCl}$ & + & + & + & - & + \\
Flexirubin-type pigments & - & - & - & + & + \\
Acid production from & + & $-*$ & - & $\mathrm{ND}$ & - \\
$\quad$ carbohydrates & & & & & \\
Hydrolysis of: & & & & & \\
$\quad$ Gelatin & + & + & - & + & + \\
$\quad$ Starch & - & + & + & + & + \\
$\quad$ Agar & - & - & - & $\mathrm{ND}$ & - \\
$\quad$ Aesculin & + & - & + & - & - \\
$\quad$-Galactosidase activity & + & - & - & - & - \\
DNA G+C content (mol\%) & 38.6 & $30^{*}$ & 34.5 & 34 & 36.7 \\
& & & & & \\
\hline
\end{tabular}

${ }^{\star}$ Data from Van Trappen et al. (2003).

The two strains differed, however, in their respective proportions of a number of fatty acids, particularly iso$\mathrm{C}_{15: 0}$, anteiso- $\mathrm{C}_{15: 0}$ and summed feature 3 .

The G+C content of the chromosomal DNA was determined according to the method described by Mesbah \& Whitman (1989) using reversed-phase HPLC. The DNA G + C content of strain $\mathrm{F} 44-8^{\mathrm{T}}$ was $38.6 \mathrm{~mol} \%$, which is consistent with the range reported for the genus Flavobacterium (30-41 mol\%; Liu et al., 2008).

Strain F44- $8^{\mathrm{T}}$ was allocated to the genus Flavobacterium on the basis of $16 \mathrm{~S}$ rRNA gene sequence analysis, supported by morphological and physiological characteristics, respiratory quinones, fatty acid composition and $\mathrm{G}+\mathrm{C}$ content. Table 1 shows the characteristics used to distinguish strain F44- $8^{\mathrm{T}}$ from related species. On the basis of these data, strain $\mathrm{F} 44-8^{\mathrm{T}}$ represents a novel species in the genus Flavobacterium, for which the name Flavobacterium beibuense sp. nov. is proposed.

\section{Description of Flavobacterium beibuense sp. nov.}

Flavobacterium beibuense (bei.bu.en'se. N.L. neut. adj. beibuense referring to Beibu Gulf in the China Sea, the site where the type strain was isolated).

Cells are Gram-reaction-negative rods, 3.0-3.2 $\mu \mathrm{m}$ long and 1.3-1.4 $\mu \mathrm{m}$ in diameter, devoid of flagellar and gliding motility. On 216L agar, colonies are smooth, yellow, circular with regular edges and a slightly raised centre,
Table 2. Cellular fatty acid contents of strain $F 44-8^{\top}$ and related Flavobacterium type strains

Strains: $1, \mathrm{~F} 44-8^{\mathrm{T}}$ (data from this study); 2a, F. gelidilacus LMG $21477^{\mathrm{T}}$ (data from this study); 2b, F. gelidilacus (mean values for 22 strains; Van Trappen et al., 2003); 3, F. frigoris ( $n=19$; Van Trappen et al., 2004); 4, F. terrae R2A1-13 ${ }^{\mathrm{T}}$ (Weon et al., 2007); 5, F. ceti 454$2^{\mathrm{T}}$ (Vela et al., 2007). Values are percentages of total fatty acids. tr, Trace $(<1 \%)$; ND, not detected/not reported. Fatty acids amounting to $<1 \%$ of the total fatty acids in all strains are not shown.

\begin{tabular}{|c|c|c|c|c|c|c|}
\hline Fatty acid & 1 & $2 a$ & $2 \mathrm{~b}$ & 3 & 4 & 5 \\
\hline \multicolumn{7}{|l|}{ Straight chain } \\
\hline $\mathrm{C}_{16: 0}$ & $\operatorname{tr}$ & 3.0 & ND & $1.8 \pm 0.5$ & $\mathrm{ND}$ & ND \\
\hline $\mathrm{C}_{15: 0}$ & ND & ND & 10 & $6.9 \pm 1.2$ & ND & 1.8 \\
\hline $\mathrm{C}_{18: 0}$ & $\operatorname{tr}$ & 3.2 & ND & ND & ND & ND \\
\hline \multicolumn{7}{|l|}{ Unsaturated } \\
\hline $\mathrm{C}_{15: 1} \omega 6 c$ & $\operatorname{tr}$ & 4.0 & 6 & $11.3 \pm 2.2$ & 1.1 & ND \\
\hline $\mathrm{C}_{17: 1} \omega 6 c$ & 3.5 & 2.3 & 3 & $3.7 \pm 1.2$ & ND & ND \\
\hline $\mathrm{C}_{17: 1} \omega 8 c$ & $\operatorname{tr}$ & $\operatorname{tr}$ & ND & $1.1 \pm 0.3$ & ND & ND \\
\hline $\mathrm{C}_{18: 1} \omega 5 c$ & $\operatorname{tr}$ & $\operatorname{tr}$ & 1 & $\mathrm{ND}$ & ND & ND \\
\hline \multicolumn{7}{|l|}{ Branched } \\
\hline iso- $\mathrm{C}_{14: 0}$ & 1.8 & 4.3 & 4 & $3.3 \pm 1.0$ & 4.7 & $\mathrm{ND}$ \\
\hline anteiso- $C_{15: 1}$ & ND & ND & 1 & $\operatorname{tr}$ & $\mathrm{ND}$ & ND \\
\hline iso- $\mathrm{C}_{15: 1}$ & $\mathrm{ND}$ & $\mathrm{ND}$ & 10 & $2.7 \pm 0.7$ & $\mathrm{ND}$ & $\mathrm{ND}$ \\
\hline iso- $\mathrm{C}_{15: 1} \mathrm{G}$ & 11.0 & 6.1 & $\mathrm{ND}$ & $\mathrm{ND}$ & 10.7 & $\mathrm{ND}$ \\
\hline iso- $\mathrm{C}_{15: 0}$ & 23.7 & 10.5 & 12 & $7.4 \pm 1.4$ & 18.4 & 45.9 \\
\hline anteiso- $\mathrm{C}_{15: 0}$ & $\operatorname{tr}$ & 12.7 & 8 & $10.2 \pm 2.7$ & 2.8 & $\mathrm{ND}$ \\
\hline iso- $\mathrm{C}_{16: 1}$ & $\mathrm{ND}$ & $\mathrm{ND}$ & 4 & $4.4 \pm 1.2$ & $\mathrm{ND}$ & $\mathrm{ND}$ \\
\hline iso- $\mathrm{C}_{16: 1} \mathrm{H}$ & 2.1 & 4.5 & $\mathrm{ND}$ & $\mathrm{ND}$ & ND & $\mathrm{ND}$ \\
\hline iso- $\mathrm{C}_{16: 1} \mathrm{G}$ & $\mathrm{ND}$ & $\mathrm{ND}$ & $\mathrm{ND}$ & $\mathrm{ND}$ & 3.0 & ND \\
\hline iso- $\mathrm{C}_{16: 0}$ & 5.7 & 10.1 & 8 & $6.9 \pm 1.6$ & 16.6 & ND \\
\hline iso- $\mathrm{C}_{17: 1} \omega 9 c$ & 5.5 & 1.1 & 2 & $2.0 \pm 0.5$ & 6.2 & 18.9 \\
\hline \multicolumn{7}{|l|}{ Hydroxy } \\
\hline $\mathrm{C}_{15: 0} 3-\mathrm{OH}$ & 1.4 & 1.6 & 1 & $1.2 \pm 0.5$ & 2.2 & ND \\
\hline $\mathrm{C}_{16: 0} 3-\mathrm{OH}$ & $\operatorname{tr}$ & 1.9 & $\mathrm{ND}$ & $1.8 \pm 0.5$ & 1.3 & ND \\
\hline $\mathrm{C}_{17: 0} 3-\mathrm{OH}$ & $\operatorname{tr}$ & $\operatorname{tr}$ & ND & ND & 1.5 & ND \\
\hline iso- $\mathrm{C}_{14: 0} 3-\mathrm{OH}$ & $\operatorname{tr}$ & 2.0 & ND & $\mathrm{ND}$ & 1.1 & ND \\
\hline iso- $\mathrm{C}_{15: 0} 2-\mathrm{OH}$ & 1.3 & 1.5 & $\mathrm{ND}$ & $\mathrm{ND}$ & $\mathrm{ND}$ & $\mathrm{ND}$ \\
\hline iso- $\mathrm{C}_{15: 0} 3-\mathrm{OH}$ & 5.9 & 7.5 & 6 & $3.9 \pm 0.9$ & 6.7 & 3.7 \\
\hline iso- $\mathrm{C}_{16: 0} 3-\mathrm{OH}$ & 3.4 & 8.8 & 10 & $7.8 \pm 2.0$ & 5.0 & $\mathrm{ND}$ \\
\hline iso- $\mathrm{C}_{17: 0} 3-\mathrm{OH}$ & 10.7 & 4.9 & 6 & $3.4 \pm 1.3$ & 10.3 & 11.6 \\
\hline Summed feature $3^{\star}$ & 16.7 & 4.1 & 2 & $14.5 \pm 3.0$ & 1.3 & 11.5 \\
\hline
\end{tabular}

* Summed features are groups of two or three fatty acids that cannot be separated by GLC using the MIDI system. Summed feature 3 comprises iso- $\mathrm{C}_{15: 0} 2-\mathrm{OH}$ and/or $\mathrm{C}_{16: 1} \omega 7 c$.

1-2 $\mathrm{mm}$ in diameter after $72 \mathrm{~h}$ incubation at $28{ }^{\circ} \mathrm{C}$. Positive for oxidase and gelatinase activities and for hydrolysis of aesculin; weakly positive for glucose fermentation. Negative for catalase, amylase, urease, arginine dihydrolase, lysine decarboxylase, ornithine decarboxylase and tryptophan deaminase activities, indole and $\mathrm{H}_{2} \mathrm{~S}$ production, citrate utilization, acetoin production (Voges-Proskauer), lipase activity (Tween 80 ), flexirubintype pigments, nitrate reduction and hydrolysis of agar, DNA and CM-cellulose. Growth occurs with $0-9 \% \mathrm{NaCl}$ 
(optimum, $3 \%$ ) and at $4-41{ }^{\circ} \mathrm{C}$ (optimum, $28{ }^{\circ} \mathrm{C}$ ). No growth is observed at $42{ }^{\circ} \mathrm{C}$ after 7 days. Growth occurs at pH 6-8 (optimum, pH 6-7). Sensitive ( $\mu$ g per disc, unless otherwise indicated) to ampicillin (10), carbenicillin (100), cefalexin (30), cefoperazone (30), cephradin (30), chloramphenicol (30), ciprofloxacin (5), clindamycin (2), cotrimoxazole (25), erythromycin (15), furazolidone (15), norfloxacin (10), ofloxacin (5), penicillin G (10), piperacillin (100), rifampicin (5), ceftriaxone (30), tetracycline (30), vancomycin (30) and doxycycline (30). Resistant to cefazolin (30), gentamicin (10), kanamycin (30), lincomycin (2), metronidazole (5), minocycline (30), neomycin (10), oxacillin (1), polymyxin B (30 IU) and streptomycin (10). In the API ZYM strip, alkaline phosphatase, esterase lipase (C8), esterase (C4), leucine arylamidase, trypsin, valine arylamidase, $\alpha$-chymotrypsin, naphthol-AS-BI-phosphohydrolase, $\beta$-galactosidase, $\beta$-glucosidase, acid phosphatase and $\alpha$-glucosidase activities are present; weak cystine arylamidase, lipase (C14) and $\alpha$-galactosidase activities are present and $N$-acetyl- $\beta$-glucosaminidase, $\alpha$-fucosidase, $\alpha$-mannosidase and $\beta$-glucuronidase activities are absent. Maltose is the only carbon source utilized in the API 20NE and API 20E strips. Starch, amygdalin, arbutin, cellobiose, D-fructose, D-mannose, sucrose, D-sorbitol, trehalose, aesculin ferric citrate, gentiobiose, glycogen, L-rhamnose, potassium 5-ketogluconate, potassium gluconate, salicin and xylitol are utilized in the API 50CH kit. The major fatty acids are iso- $\mathrm{C}_{15: 0}$, summed feature 3 (iso$\mathrm{C}_{15: 0} 2-\mathrm{OH}$ and/or $\left.\mathrm{C}_{16: 1} \omega 7 c\right)$, iso- $\mathrm{C}_{15: 1} \mathrm{G}$ and iso- $\mathrm{C}_{17: 0}$ 3-OH. MK-6 is the major respiratory quinone.

The type strain is $\mathrm{F} 44-8^{\mathrm{T}}$ (=CCTCC AB $209067^{\mathrm{T}}=\mathrm{LMG}$ $25233^{\mathrm{T}}=$ MCCC $1 \mathrm{~A} 02877^{\mathrm{T}}$ ), isolated from marine sediment of the Beibu Gulf, PR China. The DNA G + C content of the type strain is $38.6 \mathrm{~mol} \%$.

\section{Acknowledgements}

This work was supported financially by the Sci \& Tech Project of Fujian Province of China (no. 2009H0029) and the National Infrastructure of Natural Resources for Science and Technology Program of China (2005DKA21209).

\section{References}

Ausubel, F. M., Brent, R., Kingston, R. E., Moore, D. D., Seidman, J. G., Smith, J. A. \& Struhl, K. (editors) (1995). Short Protocols in Molecular Biology: a Compendium of Methods from Current Protocols in Molecular Biology, 3rd edn. New York: Wiley.

Bergey, D. H., Harrison, F. C., Breed, R. S., Hammer, B. W. \& Huntoon, F. M. (editors) (1923). Bergey's Manual of Determinative Bacteriology. Baltimore: Williams \& Wilkins.

Bernardet, J.-F. \& Bowman, J. (2006). The genus Flavobacterium. In The Prokaryotes: a Handbook on the Biology of Bacteria, 3rd edn, vol. 7, pp. 481-531. Edited by M. Dworkin, S. Falkow, E. Rosenberg, K. H. Schleifer \& E. Stackebrandt. New York: Springer.

Bernardet, J.-F. \& Nakagawa, Y. (2006). An introduction to the family Flavobacteriaceae. In The Prokaryotes: a Handbook on the Biology of Bacteria, 3rd edn, vol. 7, pp. 455-480. Edited by
M. Dworkin, S. Falkow, E. Rosenberg, K. H. Schleifer \& E. Stackebrandt. New York: Springer.

Bernardet, J.-F., Segers, P., Vancanneyt, M., Berthe, F., Kersters, K. \& Vandamme, P. (1996). Cutting a Gordian knot: emended classification and description of the genus Flavobacterium, emended description of the family Flavobacteriaceae, and proposal of Flavobacterium hydatis nom. nov. (basonym, Cytophaga aquatilis Strohl and Tait 1978). Int J Syst Bacteriol 46, 128-148.

Bernardet, J.-F., Nakagawa, Y. \& Holmes, B. (2002). Proposed minimal standards for describing new taxa of the family Flavobacteriaceae and emended description of the family. Int J Syst Evol Microbiol 52, 1049-1070.

Dong, X.-Z. \& Cai, M.-Y. (2001). Determinative Manual for Routine Bacteriology. Beijing: Scientific Press (English translation).

Kimura, M. (1980). A simple model for estimating evolutionary rates of base substitutions through comparative studies of nucleotide sequences. J Mol Evol 16, 111-120.

Lai, Q., Yuan, J., Gu, L. \& Shao, Z. (2009). Marispirillum indicum gen. nov., sp. nov., isolated from a deep-sea environment. Int J Syst Evol Microbiol 59, 1278-1281.

Liu, C. \& Shao, Z. (2005). Alcanivorax dieselolei sp. nov., a novel alkane-degrading bacterium isolated from sea water and deep-sea sediment. Int J Syst Evol Microbiol 55, 1181-1186.

Liu, H., Liu, R., Yang, S.-Y., Gao, W.-K., Zhang, C.-X., Zhang, K.-Y. \& Lai, R. (2008). Flavobacterium anhuiense sp. nov., isolated from field soil. Int J Syst Evol Microbiol 58, 756-760.

Mandri, T. \& Lin, J. (2007). Isolation and characterization of engine oil degrading indigenous microrganisms in Kwazulu-Natal, South Africa. Afr J Biotechnol 6, 23-27.

Mesbah, M. \& Whitman, W. B. (1989). Measurement of deoxyguanosine/thymidine ratios in complex mixtures by high-performance liquid chromatography for determination of the mole percentage guanine + cytosine of DNA. J Chromatogr 479, 297-306.

Rzhetsky, A. \& Nei, M. (1992). A simple method for estimating and testing minimum evolution trees. Mol Biol Evol 9, 945-967.

Rzhetsky, A. \& Nei, M. (1993). Theoretical foundation of the minimum-evolution method of phylogenetic inference. Mol Biol Evol 10, 1073-1095.

Saitou, N. \& Nei, M. (1987). The neighbor-joining method: a new method for reconstructing phylogenetic trees. Mol Biol Evol 4, 406425.

Sasser, M. (1990). Identification of bacteria by gas chromatography of cellular fatty acids, Technical Note 101. Newark, DE: MIDI.

Shieh, W. Y., Chen, Y.-W., Chaw, S.-M. \& Chiu, H.-H. (2003). Vibrio ruber sp. nov., a red, facultatively anaerobic, marine bacterium isolated from sea water. Int J Syst Evol Microbiol 53, 479-484.

Stackebrandt, E. \& Goebel, B. M. (1994). Taxonomic note: a place for DNA-DNA reassociation and $16 \mathrm{~S}$ rRNA sequence analysis in the present species definition in bacteriology. Int J Syst Bacteriol 44, 846849.

Tamura, K., Dudley, J., Nei, M. \& Kumar, S. (2007). MEGA4: molecular evolutionary genetics analysis (MEGA) software version 4.0. Mol Biol Evol 24, 1596-1599.

Van Trappen, S., Mergaert, J. \& Swings, J. (2003). Flavobacterium gelidilacus sp. nov., isolated from microbial mats in Antarctic lakes. Int J Syst Evol Microbiol 53, 1241-1245.

Van Trappen, S., Vandecandelaere, I., Mergaert, J. \& Swings, J. (2004). Flavobacterium degerlachei sp. nov., Flavobacterium frigoris sp. nov. and Flavobacterium micromati sp. nov., novel psychrophilic bacteria isolated from microbial mats in Antarctic lakes. Int J Syst Evol Microbiol 54, 85-92. 
Vela, A. I., Fernandez, A., Sánchez-Porro, C., Sierra, E., Mendez, M., Arbelo, M., Ventosa, A., Domínguez, L. \& Fernández-Garayzábal, J. F. (2007). Flavobacterium ceti sp. nov., isolated from beaked whales (Ziphius cavirostris). Int J Syst Evol Microbiol 57, 2604-2608.
Weon, H.-Y., Song, M.-H., Son, J.-A., Kim, B.-Y., Kwon, S.-W., Go, S.-J. \& Stackebrandt, E. (2007). Flavobacterium terrae sp. nov. and Flavobacterium cucumis sp. nov., isolated from greenhouse soil. Int $J$ Syst Evol Microbiol 57, 1594-1598. 